\title{
マイクロ・ナノ成形の展望
}

\section{前田 龍太郎}

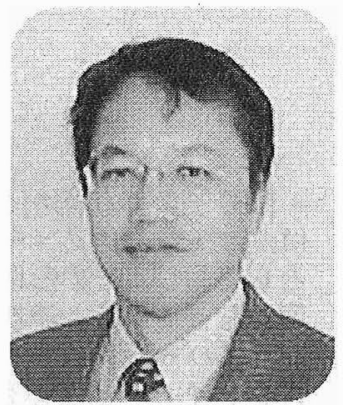

\section{微細成形への期待}

大量生産の製品を中心にものづくりの中国シフトが急速に進行している。国内産業の空洞化を嘆く時代か ら，わが国の製造業は研究開発型への脱皮を図る時代に移っている。すでに微細製造やシステムLSI 技術を ベースとして，デジカメ，DVD，プラズマテレビの分野でわが国は世界をリードしつつある。今後とあ基礎 的研究成果やアイデアをいかに迅速にビジネスに結びつけるか。微細加工を取扱う MEMS 技術やナノテク ノロジーに加加期待は大きく，産業競争力，ひいては日本の浮沈がかかっているといってる過言でない。

\section{マイクロ分野への応用}

マイクロマシン技術は微小なモーターや歯車を半導体加工技術により製作することから始まった。米国で はこの技術を MEMS (Micro Electro Mechanical Systems) と呼び，欧州では Micro System Technology 之呼ぶことが多い。現在までにこの技術により実用化されたものは, 自動車用の圧力センサーや，エアバッ グ用の加速度センサーが有名である。またインクジェットプリンタヘッドや 100 万個の微小ミラーを利用し たテキサスインストルメントの DMD (Digital Mirror Device) が知られている。この技術の近い未来の応用 分野として期待される大きな分野としては, 微小で高度な機能を有した光学部品を取扱う Optical MEMS, および流体を操作する Fluidic MEMS あるいは Bio MEMS の 2 つの応用研究開発が欧米を中心に活況を呈 している。よくに後者の Fluidic MEMS は生化学分析, 化学合成を行う微小なシステムや人工臟器などに将 来の大きなマーケットが見込まれる。Optical MEMSについても光クロスコネクトなどの開発か欧米では活 況を呈している。さらに携帯端末などの高周波部品を対象としたRFMEMSなどが新しい分野として期待さ れている。こ扎を半導体加工て製作するにはコストが高く，成形技術に対する期待も大きい。

\section{ナノ分野への展開}

一方，ここ数年ミクロンオーダーの加工技術をベースとしたマイクロマシン技術に続き，ナノオーダーの 材料・加工技術も注目をを集めている。情報通信やバイオ・エネルギーへの広範な応用が期待されているため である。ナノレベルの構造が必要な例としては通信に用いられるフォトニック素子（レーザ，スイッチ，プ リズムなど), 電気化学反応を促進する電池の陽極, 遺伝子分離用フィルター, マイクロ化学反応用触媒担持 構造などが発表されている。ミクロンオーダーの加工が半導体リソグラフィーを基本技術とした光学の取扱 う領域だったのに比べ，ナノオーダーでの加工では電子線での描画より細かいパターンの創製や転写が必要 となる。またナノオーダーの構造を電子線で描画するには, 多大なコストあかかる。機械的なコンタクトに 基づいた成形加工はその解像度と経済性により見直されている。

\section{今後の競争力を強化するために}

本特集号には上記のような観点から今後期待される技術に関して解説がなされている。ここで見られるよ うに微細加工技術之高分子技術の融合により, 有用な工業製品が開発されるものと期待される。最後に今後 の発展のために, 問題点を指摘したい。高分子はこれまでエレクトロニクスを中心に開発が進められてきた。 そこで要求される仕様は, 絶縁性, 高周波特性などの電気特性, 温度特性, 感光特性や耐久性であった。今 後マイクロ・ナノ成形分野では上記の特性に加え光学特性, 化学特性, 機械特性など多くの物性に対して ユーザーからの要求に応えなければならない。高分子はリットル単位でしか購入を受け付けず，さまざまな 種類の高分子を応用しようとするユーザーの研究開発の障害となっている。今後業界を超えた密接な連携が 期待される。わが国が培ってきた高度な微細・精密加工技術之高分子をはじめとする機能材料に関する材料 技術の連携こそが，簡単に模做することのできない差別化技術の醸成とわが国競争力の強化につながると期 待する。

MAEDA, Ryutaro 産業技術総合研究所 機械システム研究部門集積機械研究グループ（305-8564つくば市並木 1-2-1）・研究グルー プ長. 1980 年 東京大学大学院工学系研究科金属工学専攻修士課程修了. 専門は微細加工. 